\title{
Integrating biosemiotics: From a semiological point of view
}

\author{
Adrian Pablé ${ }^{1}$
}

\begin{abstract}
This paper is a study in the 'philosophy of semiotics'. It is centred on a critical approach to the Peircean sign conception, which underlies biosemiotics and the global perspective on signs. The present discussion tackles questions of ontological and epistemological interest, which it does by taking a distinctly semiological point of reference. The semiology which the present critique draws inspiration from is Roy Harris' integrationism, an approach to human communication which rejects Saussurean semiology - the common target of Peircean semiotics. Integrationism explains signs in relation to human activities. It shares with biosemiotics a view of reality as speciesspecific, but takes a skeptical position towards the investigation of non-human signs on the grounds that it implies a metalanguage impervious to the radical indeterminacy of the sign. Integrationists take this indeterminacy as the starting point for their reflections on human communication.
\end{abstract}

Keywords: biosemiotics; integrationism; Charles Peirce; Roy Harris; semiology; philosophy of semiotics

\section{Introduction: semiology vs. semiotics}

Adherents to a Peircean semiotics have long criticized what could rightly be called its sister discipline, Saussurean semiology, for its mistakenly treating the part as the whole, i.e. by committing the so-called 'pars pro toto fallacy'. As Susan Petrilli $(2011 ; 2015)$ has argued, semiologists have put the verbal sign on a pedestal, i.e. they assume verbal semiosis to be the model for all sign processes. Thus, Saussure's programmatic statement that semiology would study signs "as part of social life", as he famously put it in the Course in General Linguistics (Saussure 1983: 15), led to the assumption, in the wake of the Structuralist Revolution, that signs were ipso facto linguistic signs, which had no independent existence outside the abstract social structure to which they belonged. To Petrilli (2011: 297), the claim

1 School of English, Faculty of Arts, University of Hong Kong, Pokfulam, Hong Kong S.A.R.; e-mail: apable@hku.hk. 
that semiology is the general science of signs appears as incorrect and even as a "mystification". Charles S. Peirce, however, developed a triadic sign model that was able to accommodate both natural and man-made signs, and no longer restricted 'communication' to human (linguistic) communication. Semiotics, understood as the truly general study of signs, is Peircean in its orientation for that very reason. Thomas Sebeok (1979) saw the study of signs as transiting from "code semiotics", centred on linguistics, to "interpretation semiotics", which "also accounts for the autonomy and arbitrariness of nonverbal signs, whether 'cultural' or 'natural"' (Petrilli 2011: 298).

The present paper is a plea for semiology, though not in the traditional sense. It intends to introduce the Peircean semiotician to a different semiological approach than Saussure's: one that fully acknowledges Saussure's historical contribution to semiology but at the same time radically departs from its basic premisses and from its idealism. It is a semiology that is never (critically) discussed by semioticians as part of the semiotics-semiology controversy (e.g. Sebeok 1979; Deely 2003; Petrilli 2015), with the laudable exception of Paul Cobley (e.g. 2011a; 2014; 2017). The present contribution, it is hoped, will enrich the (yet to be invented?) field of philosophy of semiotics, i.e. it constitutes an opportunity for semioticians to defend their own views of the sign in light of the semiological considerations presented here. The semiology I am referring to relies on an integrational conception of the sign, as outlined in the many works of Oxford linguist Roy Harris (1931-2015). Said conception received its clearest formulation in a piece published within the collection Integrationist Notes and Papers (Harris 2009a). As a Saussure scholar and trained philologist, Harris was naturally interested in human signs, and linguistic signs in particular. However, in the late 1970s his linguistic thought developed in a different direction from mainstream linguistics, ultimately leading to an approach he chose to call integrational linguistics and integrationism. Harrisian semiology shares with its Saussurean counterpart a commitment towards human signs as well as an "anti-surrogational" view of signs, i.e. the rejection of the notion that a sign is something that "stands for" (or, is "a surrogate" of) something other than itself. This rejection is arguably what separates semiology from semiotics. It is also the reason why semiology is not part of semiotics from an integrational standpoint.

While critiquing the Saussurean sign is relatively straightforward from a Peircean perspective - signs are not only conventional and in the possession of a collective unconscious: some signs are based on causal relationships or natural connections, whereas others are based on resemblance or imitation -, it is not quite clear how the Peircean scholar will (critically) deal with the sign as conceived by the Harrisian integrationist. Peirce's sign is linked to the notion of semiosis, or as Deely (2009: 25) puts it, "the action of signs". The Harrisian semiologist, in turn, 
does not view signs as 'acting' but as being made. This paper intends to initiate such a discussion - recent attempts at rousing the interest of semioticians have largely remained unreciprocated (Pablé 2016; Pablé, Hutton 2015) - by showing both the theoretical common and uncommon grounds between integrationism and a Peircean-inspired semiotics - as seen from an integrational point of view. The focus in the present contribution will be on biosemiotics as the successor discipline to semiotics (Cobley 2016), which recognizes that

not just a semiotics of human communication is needed, but, in addition to zoosemiotics, a semiotics of plants ('phytosemiotics'), of fungi ('mycosemotics'), and of the 3.5 billion year old global prokaryotic communication network within and between different bacterial cells ('microsemiotics, cytosemiotics'). (Cobley 2016: 19)

As Cobley (2016: 18) further puts it, biosemiotics distances itself from a semiotics subject to the 'linguistic turn', which assumes that "much of human life is 'constructed in discourse". Biosemiotics, in turn, proposes to study the human being endosemiotically, i.e. as a "mass of signs enacting message transfer nonverbally within the body" (Cobley 2016: 19). Conceived in this manner, the sign conception adopted in biosemiotics is antithetical to a Saussurean-inspired semiology. Deely (2009: 129), however, has called for an "amalgamation" of the Peircean and the Saussurean sign models, i.e., following Sebeok, he insists that semiology is part of semiotics, adding that the Saussurean notion of code (as an autonomous linguistic system) is indispensable for a conception of the linguistic sign as a triadic relation (Deely 2009: 130). In light of this, it is not clear whether biosemiotics constitutes a radical departure from structuralist approaches to the notion of 'a language'. As Cobley (2014) has argued, semioticians have held very different views on 'codes' (both linguistic and non-linguistic). Generally speaking, however, semioticians seem to reject a purely code-based model of verbal communication, the latter being understood as much more than encoding and decoding linguistic signs that lead an existence separate from the material world (or rather: the 'objective' world), which makes a comparison with integrationism all the more compelling. In its anti-idealist position on reality, semiotics relies on a seminal distinction between 'things' and 'objects' (Deely 2003; 2009) in (rightly) promoting semiotics as the more advanced approach to reality than orthodox science.

In this paper I shall pinpoint what I see as relevant differences between the two approaches under scrutiny, always in relation to their respective sign conceptions. My point of departure lies in questions in the philosophy of communication, which include numerous interdependent questions, among them 'What is 
communication?' and 'What is a sign?'. This particular focus is a consequence of the present article being written from an integrationist perspective, which takes an experience-based approach to human communication. It is an approach that is quite incompatible with any structuralist understanding. Any discipline dealing with communication and taking the sign as its central concept (as does semiotics, and, though more covertly, do most branches of mainstream linguistics) is discussed by the integrationist from a Harrisian semiological perspective. It is certainly not the only possible perspective, but one that still is still awaiting a serious critical response.

\section{The biosemiotic view}

Biosemiotics is concerned with studying the communicative behaviour of living organisms. Following Sebeok, biosemiotics is synonymous with global semiotics, the study of the "life of signs" and the "signs of life" (Sebeok 1979). A seminal notion within biosemiotics is that of umwelt, as developed by biologist Jakob von Uexküll (1982), which has played a crucial role in the decentring of what Sebeok called 'anthroposemiotics'. According to Uexküll, all species inhabit an 'objective world' - the 'public' world of a species, which is made of 'objects'. Uexküll called this the species-specific umwelt. As already the seventeenth-century thinker John Poinsot pointed out (an insight further developed by philosopher John Deely), 'objects' are always objects of experience, requiring awareness (they are minddependent). The objective world is constituted by how the animal maps the world through its Innenwelt (the inner, subjective world) through which the meanings of objects are determined (via signs). The semiotician calls this mapping of the world 'modelling' (Kull 2010: 43). Thus objects are not by themselves objects, as Deely (2009) makes clear: they are 'things' which become objects every time they are experienced by a species through signs of their own (species-specific) making.

As Cobley (2016: 21) explains, Peirce's definition of the sign as "something that stands to somebody for something in some respect or capacity" (CP 2.228) parallels von Uexküll's notion that signs are products of species-specific sensoria. Moreover, Charles Morris noted that Peirce's "to somebody" also applies to members of a non-human species, i.e. to all living organisms (Petrilli 2011:296), which logically follows from the premiss that signs are not an exclusively human phenomenon - quite the contrary: according to biosemiotics, human signs, although occupying a special place in the 'semiosphere' (because of 'language'), are marginal, both numerically and historically speaking. Distancing itself from Saussurean semiology, biosemiotics sees itself as much more ambitious in 
scope, aiming to investigate how organisms 'know'. It is the science of knowing in the circumstances that the species finds itself, and hence its goal of nonanthropomorphic observation, i.e. investigation on the terms of the species (Cobley 2016: 39). The biosemiotician starts from the conviction that the Peircean triadic sign (sign-object-interpretant) is an "attribute of all life" (Kull 2011: 236), including human life. The emphasis in this sign model is, as Deely (2009: 154) explains, not merely between two elements (sign-object) in a dyadic relationship, but always also in relation to the mind/organism doing the interpreting (triadic relationship). This relation to the interpreter (human or non-human) makes an 'object' out of a 'thing. Peirce's sign conception is seen as depicting a universal semiotic reality, which at the same time reflects a historical reality: bacteria, for example, were engaged in semiosis (message exchanges) long before humans were.

Concerning the object-thing dichotomy, it was John Deely's (2009: 161) crucial insight that only humans can contemplate things in and for themselves, while nonhuman species cannot reach beyond their 'objective' world, i.e. they cannot subject signs to analysis because they lack the kind of reflexivity humans possess. For nonhuman animals, therefore, the sign and the object are one and the same, while only humans can become aware of their difference: animals are "semiosic", but humans are also "semiotic" (Deely 2009: 162). However, not even humans can study pure things (in spite of what scientists believe), i.e. they cannot 'overcome' their own sensoria in their investigations of brute physical reality. While recognizing the complexity of the human umwelt and Innenwelt, which includes, as Sebeok argues, 'language' as the "primary modelling device" constituting the human Innenwelt (Petrilli, Ponzio 2011: 318), biosemiotics rejects human exceptionalism (and the humanist glottocentric position that goes with it) and instead invokes the antiCartesian principle of continuity (synechism), which dissolves the ('mystical') differences between mind and matter, and ultimately between non-humans and humans. Human knowing, as Cobley (2016: 42) puts it, is continuous with semiotic processes in other organisms. Following the same logic, the principle also dictates that a global semiotics be concerned with semiosis (continuity across the realm of nature) rather than with the individual sign (Cobley 2016: 25).

The biosemiotic view of what it means to be human and a human subject seeks to invalidate the Cartesian perspective and implement the endosemiotic perspective. As Jesper Hoffmeyer (1996: 23) argues, the human being is, in fact, "the product of a collaboration between possibly hundreds of trillions of bacteria", adding that these bacteria "collaborate on the job of being human" (Hoffmeyer 1996: 124). Based on this, Cobley (2016: 46) remarks that individualism is an untenable idea (citing Peirce's outright rejection of the common belief in unique individuality): in fact, being constituted by endosemiosis, humans are seen 
as "subject to collectivity" (Cobley 2016: 47). Moreover, humans are always also subject to an 'other'; or to put it in Peirce's terms, "your neighbors are, in a measure, yourself" (CP 7.571). As Cobley (2011b: 107) notes on that score, Sebeok considered interpretation always in relation to an 'other'. Moreover, Sebeok had no qualms about extending the notion of the 'self' (and a sense of self) as well as the act of interpretation to non-human creatures. In the human realm, he distinguished between the biochemical self (with semiotic overtones) and the social self (with a biological anchoring), neither of which exist in isolation. The 'other' that the self relates to is not an option (which one chooses to enter in dialogue with) but an inevitability. Sebeok's vision of the self emphasizes the confluence of both natural and cultural processes - a rejection of the idea that the self is merely constructed through language and discourse. Being deeply anti-humanist, biosemiotics denies that agency and intentionality are exclusively human attributes. If they were, how could other organisms be sign-makers (or sign-users), i.e. communicate via signs? In view of this, it comes perhaps as no surprise that biosemiotics applies the notion of 'activity' very broadly, saying of both bacteria and humans that they engage in activities which presuppose signs and interpretations. Human knowledge thus comes to be seen as the product of endosemiosic activities (Deely 2009: 132), including the human mind.

\section{The integrationist view}

Harrisian integrationism, discussed most thoroughly in Harris' two consecutive book Signs, Language and Communication (Harris 1996) and Introduction to Integrational Linguistics (Harris 1998), takes a view on signs and sign-making that is altogether humanist. However, unlike traditional humanism, it is not elitist it is 'lay-oriented' in a particular sense (Pablé 2019a). Harris rejects many of the traditional notions about human communication and the role of 'language' and 'languages' associated with humanism, referring to them collectively as the Language Myth (Harris 1981). However, his critique of what semioticians call 'glottocentrism' has a different angle. Harris argued that a theory of human communication that aspires to be a general theory needed to orient itself towards the goal of understanding linguistic experience from the inside, i.e. it should contribute towards self-knowledge rather than introducing abstractions that eliminate linguistic experience itself, as mainstream linguistics had arguably done (Harris 2010). In fact, mainstream linguistics, depite its claims to being a 'science', could actually be accused of harbouring a cultural bias in the way it investigates and describes human languages: thus while defining 'languages' as abstract systems 
of signs shared by the members of a collectivity, it also proclaims the professional linguist to be an expert whose knowledge transcends the limitations of the lay linguistic user. The view of 'languages' as consisting each of identifiable (though only interdependently existing) abstract signs amenable to scientific description was indeed the result of a Western idea, originally developed in nineteenth-century Europe, modelled on the natural sciences, which, Harris (2005) has argued, are equally underwritten by the Language Myth. On this view, science is grounded in a Eurocentric conception of how language relates to the world, i.e. the belief in true names, which correctly identify the things they are names of, irrespective of contextual factors.

For the integrationist, in turn, there are no linguistic experts because there are no scientifically describable objects called 'languages' which define human communication for what it is. This means that the linguistic sign does not occupy any privileged place in integrationist theorizing - still, Harris insisted that an integrational theory of communication had to be semiologically grounded (Harris 1996: 12). Integrationists focus on the notion of activity as a fundamental lay concept when it comes to understanding human communication, and theorize communication processes as consisting of activities that are integrated by means of contextualized signs of all kinds. The notion of a 'linguistic sign', as theorized in mainstream linguistics, is rejected by the integrationist as an unwarranted extrapolation detached from the concrete (first-order) sign-making processes individuals engage in, for whom the 'linguistic' and the 'non-linguistic' are not separate but always integrated domains of knowledge, as stated by the 'principle of cotemporality' (Harris 1998).

In other words, what matters in human life is that activities of whatever kind are integrated by whatever semiological means are available to individuals engaged in a specific programme in order to further their specific communicational objectives. A simple (imagined) scenario might help to clarify why integrationists hold communication to be radically open-ended: I hear the doorbell ring (an acoustic stimulus integrated by me and made meaningful) but I'm sitting at the desk writing the present piece (a programme of various activities I have been and currently am engaged in with a specific goal set in the near future), so I ask my son, who is sitting on the sofa playing Fortnite, to please go check who it is (the activity of saying something to someone else in the circumstances as they pertain). My son complies with my request (a disruption of my son's programme of activities and taking up a new activity presupposing knowledge of what to do and the ability to exercise certain other activities: to be able to walk, to have the necessary height to open the door and knowledge of how to open it, greeting the other person, assess the situation, deciding what to do next, etc.). Unlimited possibilities arise out of the 
scenario described above, allowing for various alterations: for instance, my son may be wearing headphones and not hear my request. I have to repeat it while speaking louder. Or it turns out that I only heard the doorbell ring after two failed attempts. I learn about it when opening the door myself due to my son's refusal to comply. Perhaps my son did not hear it, either, or perhaps he did but did not bother to take any action. And so on.

Regarding the ontology of the sign, the integrationist holds that the signs made on the various occasions are unique. To some they were repetitions, to others they were not. In this respect, the integrationist does not accept that there are 'facts' (linguistic and otherwise) that can be established independently of the sign-makers themselves (Harris 1998). Crucially, however, even a sign repeated is, from an integrational semiological point of view, a creation ex nihilo: its creation occurs in a new situation, but its integrational function relies on its being construed by the sign-maker(s) as having a predecessor sign. The first sign (ringing the doorbell for the first time) and the second sign (ringing the doorbell for the second time) cannot possibly mean 'the same' for the person ringing (nor for the person hearing them).

In Harris' view, signs are thus the products of contextualization: they both result from and facilitate the integration of particular activities in particular circumstances (Harris 2006). Integrationists recognize that we are always circumstantially determined, aware of ourselves, which is why the here-and-now is communicationally constrained for any individual by factors of three kinds, namely (i) biomechanical factors, which relate to the physical and mental capacities of the human being, (ii) circumstantial factors, which relate to the specifics of particular situations, and (iii) macrosocial factors, which relate to practices established in the community (Harris 1998: 29). Integration in any semiologically relevant sense is the individual's continuous integration of (remembered) past and (anticipated) future with the here-and-now, which, the integrationist argues, cannot rely on a set of shared abstract signs but necessitates the making of signs. To manage the daily integrational tasks is to know how activities are temporally integrated in the macrosocial patterns of the community and to act accordingly (while acknowledging that not doing anything may also be a form of action).

Integrationists reject the two fallacies known as the 'fallacy of telementation' and the 'fixed-code fallacy', which explain the role of words as enabling speakers of the 'same language' to transfer mental concepts from one mind to another, resulting in mutual understanding. In turn, the integrationist regards 'languages' and 'words' as second-order abstractions and hence as products of human communication not its prerequisites. Since integrationists accept communicational activities of the first-order as the only reality, they view signs as spontaneous creations of the individual's mind, i.e. they are, as Harris (2009a) puts it, radically indeterminate 
(in both form and meaning). Harris (2006: 715) further says about the sign that "it exists as a construct by reference to which certain communicational activities [...] are integrated", adding that apart from such activities "the sign as such has no existence". All signs must be integrated ones because there is no sign without its personal maker. It follows that the integrationist rejects the substitute (or surrogational) sign (Harris 1996), i.e. the idea that a sign is anything that 'stands for' anything other than itself (a thing, an idea, a kind of behaviour) as well as the Saussurean sign, i.e. the idea that signs are defined purely internally by the abstract (linguistic) system to which they belong. The integrationist, in turn, stresses the temporality of the sign, and what it 'means' is always in relation to its integrational function, i.e. 'meaning' cannot exist as an abstraction. Harris, therefore, proposes a conception of the sign which is radical in many ways by proposing a semiology grounded in first-person experience.

\section{Human signs and non-human signs}

Peirce's dictum that "man is a sign" (CP 5.314) would be rephrased by the integrationist as "man makes signs", the reason being that signs cannot make signs. It is certainly true that living requires sign-making, and that the activity of interpreting coincides with one's life, as Sebeok put it. To say of oneself, as Sebeok (1986) did, that one is therefore a verb (because of this activity of interpreting) - rather than a noun - comes close to committing the fallacy of verbalism that semioticians have so vehemently distanced themselves from: from an integrationist point of view, human interpreting is not ipso facto the domain of 'language'. For the integrationist, many kinds of experiences are 'prelinguistic' - so-called not because they occur in the human's early prelinguistic stage, but because they do not involve "linguistic communication" (Deely 2009: 156), but may be followed by a verbal exchange or by the activity of talking to oneself. Harris' example concerns a visual experience, namely that of him looking out of the window and seeing a cat at the end of his garden (Harris 2009b). Self-understanding, for Harris, consists precisely in rejecting a 'glottocentric' view of ourselves, i.e. we are not "apes plus language" (Deacon 1997: 5), even though 'language' is without a doubt an important kind of integrated activity within the human umwelt.

For example, verbal communication enters the picture in the aforementioned scenario when Harris, on seeing the cat in his garden, turns to someone else in the room and informs him/her of it. What matters in this respect is that talking to someone else (dialogic communication) involves a very different order of integration and knowledge than observing (non-verbal self-communication). 
Observing is not a form of self-talk. According to Harris, seeing a cat at the bottom of one's garden is a personal interpretation of a visual stimulus and thus requires the making of signs. And this is where the Harrisian and the Peircean sign conceptions are at odds: to say that $a$ sign cannot be a sign of itself, as Peirceans do, is not something that the integrationist would subscribe to, as the latter does not define the sign surrogationally, i.e. as anything that 'stands for' anything other than itself. In Harris' example, observing is an activity one engages in against a certain macrosocial background (e.g. staring out of the window into the garden may not be considered polite, especially not when in somebody else's home), under certain circumstances and through the exercise of certain biomechanical capacities (e.g. it is still daylight, Harris happens to be wearing his glasses, he happens to be standing by the window looking into his garden, the bottom of his garden happens to be near enough for him to recognise the cat, etc.).

Integrational semiology does not theorize signs as tripartite (sign-objectinterpreter) or internally relational, as the sign only exists to fulfill an integrational function for someone in the here-and-now. There is no further (more developed) sign triggered in the mind (interpretant) by the sign itself (representamen) because for the integrationist the sign itself does not exist. The rejection of the sign (in this Harrisian sense) is a direct consequence of treating signs as radically indeterminate in both form and meaning. The word sign itself is no exception to this. As Harris (2009a) makes clear - like Saussure before him - the human sign does not have a physical constitution: what we commonly call 'signs' (billboards, road signs, zebra crossings, etc.) are not signs from a (Harrisian) semiological point of view. Deely (2009: 162), concords, stating that signs are not a particular class of objects, though some material signs, in a Peircean framework, would count as potential human signs even before they are interpreted as such (Petrilli 2015). Moreover, Peirceans do not view the sign as belonging to the "sphere of the visible" (Deely 2009: 143). The sign is said to be "invisible" because what makes the sign is its triadic relation, and relations are not perceptible to the senses.

However, in the Peircean model signhood inheres in the object (as a potentiality) with respect to the already existing umwelten. Hence it is only a matter of time before something becomes a sign to 'someone'. In fact, communication is not seen as radically open-ended in semiotics (as opposed to integrationism). The (material) object is a crucial component in the Peircean triadic sign conception, while for the integrationist signs are 'internal' creations by human sign-makers (a different conception of 'invisibility'), while objects only have an existence as part of human activities (engaged in by particular individuals), which give rise to signmaking. The exact identity of the objects, which is tantamount to stating what they are called correctly, is not necessarily pertinent to first-order integrated activities. 
Signs exist for the sole purpose of integrating human activities that would otherwise (i.e. without those signs) remain unintegrated, and those activities often involve 'objects'. The Harrisian semiological stance must not be mistaken for an idealist position, as the signs 'integrate' activities of both the 'inner' world and the 'outer' world. Integrationism is thus grounded in the material world, but at the same time emphasizes that sign-making presupposes the individual human mind.

From an integrational point of view, neither model, dyadic or triadic, can provide a satisfactory explanation of what a sign is because both models decontextualize the sign. In other words, they treat signs as separate from the activities that individuals are engaged in. What a sign is, the integrationist argues, cannot be answered from a third-person perspective, which makes the "scientific" study of human signs an impossibility: contextualization cannot be theorized beyond the lay observaton that if the signs I make are unique products of the present moment (in which certain activities are being pursued), everybody else's signs must also be unique creations. What follows from this lay insight is the theorist's rejection of the abstract sign (of whatever stamp). The conception of the sign proposed by Harris is "lay-oriented" insofar as its approach to human communication attempts to embrace the whole range of possible lay perspectives, but it arguably does not constitute a "lay theory". Patently Harris' explanation of what a sign is does not correspond in the least to how people would commonly use the English word 'sign'. Surrogational sign models of a dyadic type, in turn, are much more in line with lay ideas about signs, catering to such commonsense questions as "Of what is this or that a sign?". However, integrationism does not primarily target lay uses of the word 'sign' - nor lay ideas of what a sign might be - for its critique. Harris' "integrational" theory of communication needs to be seen as an alternative to the so-called "segregational" theories that Harris has identified (Harris 1996). The problem with decontextualization is first and foremost of a theoretical nature, i.e. it relates to the philosophies of language adopted by disciplines interested in theorizing communication. Integrationism aims to critically engage with these philosophies.

Peirce's categorization of signs into firstness, secondness and thirdness would appear to be more compatible with Harrisian semiology, emphasizing different context-dependent kinds of signhood. Thus Cobley (2016: 11) explains firstness as the realm of the possible ('feeling'), such as a vague taste or a sense of a colour. Secondness is the realm of the brutally factual, as when closing the door an object in the way prevents its complete closing, which gives rise to understanding the relation between closing the door and its failure to close. Lastly, thirdness is the realm of general laws, or the virtual, such as the law that heavy objects in the way can prevent doors from closing. The integrationist will certainly not disagree 
with the idea that signs may differ phenomenologically, but will point out that human sign-making always occurs as part of an activity - and human activities are invariably constrained by macrosocial, circumstantial and biomechanical factors. From an integrational perspective, it is not enough to specify the situation or context (closing a door and its being stuck because of a heavy object in the way): these situations do occur, as our personal experience (or our imagining such scenarios) amply testifies, but they always involve concrete individuals in concrete circumstances (even in the case of scholars introducing them to exemplify a type of situation), i.e. individuals doing something as part of an activity (whatever the activity, or activities, may be). The activities may involve several people in various ways, or may involve a single person. They may of course involve non-human creatures as well (walking the dog, feeding the cat, etc.). The contextualizations which make the signs possible, however, are always the result of individuals 'doing' something in unique situations, i.e. a phenomenological typology of signs inevitably distorts the sign-making experience here-and-now. There is nothing wrong with generalizations of experience (e.g. when we establish general laws of how objects 'behave' in relation to each other). The problem that integrationists have on that score has to do with their conviction that human signs only exist to integrate firstorder communicational activities, whereas the Peircean sign model caters to both human and non-human activities. When it comes to simple life forms, activities are reducible to behaviour which, though conditioned, is regular and predictable.

Unlike semiotics, integrationist semiology theorizes linguistic signs as radically indeterminate, including the radical indeterminacy of the metalanguage. That semiotics would not want to proclaim form and meaning to be radically indeterminate (in the Harrisian sense) is perfectly understandable: a general study of the signs in/of life - the 'life science' that biosemiotics aspires to be - relies on identifying (species-specific) signs in particular instances. There is an interesting parallel between integrationism and semiotics, though: while integrationists explain what a sign is in relation to the individual human sign-maker (hence the impossibility of a decontextualized definition), the semiotician will explain what a sign is in relation to the species and its umwelt. The difference, however, lies in the ambitious task set by global semiotics to understand what the signs mean for the different living organisms. Radical indeterminacy (in the Harrisian sense) would be a nonsensical theoretical concept for the general study of life forms: in fact, biosemiotics takes as its starting point that any stimulus can be a sign to any living organism. On this view, signs basically take over, becoming "actors" and "begetting life", while the living organisms themselves (including cognitively sophisticated beings like Homo sapiens) become "interpreters" of those acting signs. Anything, therefore, acts as a sign as long as it finds an interpreter to which to attach itself: 
thus even an animal carcass is a sign, though itself lifeless, because it will inevitably find its interpreters, i.e. it exists as different 'objects' in the various species-specific umwelten. No sign can exist without its object, which in turn cannot exist without its interpretant, but there is still the reality of the "sign-potential".

The biosemiotic view, it needs to be admitted, is an appealing one for anybody who views humanism and its core beliefs with skepticism (because of its Eurocentrism, its patriarchal ideology, its glorification of humans, particularly of Westerners, etc.). Biosemiotics purports to free the study of life of (humanistic) ideologies by granting signs and communication their rightful place in intellectual and scientific discourse - a discourse that no longer lends itself to discrimination against species, races, ethnicities, sexes or languages. Instead it proclaims that without signs and without communication nothing could have come into existence (the universe - planet Earth - human beings). Signs, together with communication, are at the forefront of the biosemiotic approach (as they are in integrationism): adopting a majestic - almost God-like - view, human life must ultimately appear as merely one particular biological development on the life continuum, albeit one of a particular kind. Hence the biosemiotician's conclusion that humans are different both in degree and kind (Cobley 2016: 43).

From the point of view of biosemiotics, the semiological fallacy consists in starting its investigation of signs by treating them as part of social (i.e. human) life, as proposed by Saussure, i.e. treating signs as belonging to the human umwelt exclusively and declaring the sign as synonymous with the linguistic sign. Biosemiotics proposes a reversal of the humanist priorities, namely a more global (and hence less biased) investigation of signs, which calls for a very different conclusion: humans are only recent sign-users (adding linguistic signs to the rich pre-human sign repertoire), which is why the study of signs (including human signs) requires a biological - not a cultural - approach (i.e. one that treats culture as part of biology). Biosemiotics does not reject the first-person experience account - Cobley (2016: 42) refers to it as "quasi-knowing" - but insists that once we see that the human umwelt is the human reality, we shall want to "move beyond" our personal experience of what a sign is (an incomplete view). An epistemological framework that aims to 'know', albeit still as humans, what non-human creatures 'know' has to rely on a third-person perspective. This, in turn, makes it indispensable for the Peircean semiotician to think of signs as other-representations, which follows directly from the position that objects 'mean' differently to different organisms (i.e. the objects have to be mediated via signs in order for them to 'mean'). Adopting a Peircean sign model, even the linguistic sign can be shown to function surrogationally as part of that complex of activities that Saussure termed 'parole'. 
The reasons for an integrationist objection to the substitute sign (including the Peircean triadic variant) should have become evident by now: only by theorizing signs as existing in virtue of their integrational function, as Harris does, can decontextualization be avoided. For a sign to be made it has to be contextualized. This personal sign cannot become impersonal for the sake of disciplinary demands, such as extending the study of signs to all living organisms. Both Sebeok (1979) and Deely (2009) have argued that Saussure's semiology can be incorporated into the global study of signs (semiotics), which is possible because Saussure's sign conception is based on the abstract sign as much as the Peircean conception. Integrational semiology, on the other hand, is incompatible with both Saussurean semiology and Peircean semiotics. Only integrationists insist that the signs of human communication are personal ones, i.e. creations ex nihilo. Bacteria and fungi, for example, are not 'persons'. If they make (or use) signs, as the semiotician claims, they are certainly 'their' signs, but as a consequence of being 'theirs' humans cannot really 'know' them.

It might be objected here that it all depends on how one defines 'knowing'. Agreed. This is itself a semiological question. However, an integrationist epistemology (Harris 2009b) cannot dispense with the radical indeterminacy of the sign: knowledge is thus never something external to the knower but something generated by the sign-maker. Knowledge is always contextualized, never contextless. It requires human signs and cannot be detached from personal experience. The integrationist conception of the sign, if accepted, does not allow one to provide a definition of non-human signs (as, then, the question what counts as a 'sign' becomes nonsensical), nor does it allow one to treat them as somewhat comparable to human integrated signs. The signs (stimuli) that bacteria 'interpret' are nothing like the signs that require the complex integration of the here-andnow with remembered past experience and anticipated future experience. The integrational sign and the substitute sign are incompatible, i.e. they go with two different conceptions of 'communication', which makes it incoherent, from an integrational perspective, to claim that humans and, say, bacteria both make 'signs'.

Of course, it could be claimed that non-human animals also 'integrate', but if they do it is hardly something that we can 'know' about, given that there are no experiences to introspect. To say, in Uexküllian fashion, that the fly knows the table as a 'landing-object', or makes it one (Uexküll 1982) is to say that this 'thing' becomes an 'object', which means that it is a sign for the fly in accordance with its Innenwelt (if it were not a sign, the table would not 'mean' anything to the fly). The integrationist argument, however, is that in the realm of animal communication our insights into signs must come from observation only. What we observe, therefore, is behaviour. Since signs are not external to the sign-maker, 
how can we observe anything that directly pertains to sign-making? Integrationists take a sceptical position on signs as 'actors' in the universe, mainly due to their anthropocentric stance when it comes to signs and communication. There is a dilemma here: semiotics - like integrationism - rejects behaviourism, which it rightly sees as reductionist. Signs are more than mere behaviour. They concern meaning. While steering clear of claims that bacteria and fungi possess 'minds', biosemiotics insists that organisms 'know' objects whenever they 'interpret' them, which in turn presupposes signs and meaning-making. Although 'knowing', 'interpreting', 'meaning-making' are human attributes (possibly including other animals supposed to have a 'mind'), semiotics says of itself that it steers clear of anthropomorphism by freeing the sign from the semiologist's grip and putting it where it rightfully belongs as a theoretical concept, namely (semiotic) biology.

\section{The object-thing distinction}

In Purely Objective Reality, John Deely (2009) resurrects the intriguing distinction between thing and object, together with the distinction between physical reality and objective reality. His approach being informed by biosemiotics, Deely rejects both naïve realism and nominalism. Building on the notion that the sign is constituted as a triadic relation, Deely affirms that reality is always 'objective' because it is species-specific and thus constrained by the sign-making capabilities of a species and its sensoria. Deely's account of how science turned to 'things as they are' (the physical environment) as its object of study and his critique of the failure on the part of scientists and philosophers to understand the difference between objects and things bears some interesting parallels with Roy Harris' argument as presented in The Semantics of Science (Harris 2005). As Deely rightly argues, only humans are capable of distinguishing between objects considered in relation to him/herself and objects considered in relation to the objects themselves, i.e. to contemplate them for their own sake (i.e. as 'things') and to treat them as 'objectively' given (whereby 'objectivity' in the latter sense is to be distinguished from 'objectivity' in the biosemiotic sense). The cardinal mistake made by orthodox science, for Deely (2009: 167), lies in assuming that the physical environment is the same regardless of the creatures that inhabit it. Deely does not deny the reality of the physical universe (as a thing): he states, in fact, that there is a physical universe which is the same for all types of organisms, but adds that this physical environment is different from the points of view of the various umwelten. Deely's crucial insight here is that science and semiotics differ in their conceptions of reality. What science fails to see is that signs "are 
indifferent to reality in the physical sense"; in other words, biosemiotics cannot adopt a 'scientific' point of view, as it corresponds to no living organism's point of view. In this view, therefore, science could be seen as a branch of anthroposemiotics, i.e. the institutionalized human activity of investigating a sign-less reality through signs (science commmunication in its various forms), a reality made of 'things', not 'objects'. However, as the semiotician would point out, it does not follow from this that biosemiotics is unscientific. Biosemiotics sees itself as the superior science compared to orthodox science because (unlike science) it realizes that the study of 'things as they are' is intrinsically part of the human umwelt, a stance made possible semiotically by human linguistic reflexivity. Biosemiotics investigates objective worlds, "the order that is created above all by the action of signs" (Deely 2009: 173). Deely (2009: 168) also points out that reality and unreality are both part of objective (species-specific) reality, while unreality does not partake of physical reality.

Deely's philosophical approach is grounded in a Peircean 'realism': he speaks of "hardcore" reality in connection with subjectivities (or substances), which are independent of human opinion. Biological relations are hardcore. For example, Deely (2009: 152) remembers the case of a girl in America (whose mother had passed away) who thought the man she lived with was her father, but, Deely tells us, she was actually the biological daughter of a man in Europe, who did not even know about her existence. As Deely points out, there exists an intersubjective relationship between the father (the man in Europe) and his daughter: two subjectivities whose connection with each other is not sign-mediated. The girl's belief that the man she calls her father is really her biological father, on the other hand, is part of the objective world, i.e. there is no intersubjective reality linking these two subjectivities: there is only a triadic relation in the form of a sign, an object and an interpretant. However, as far as that girl was concerned the integrationist objection might run - the man she lived with was her father. From the point of view of an integrational epistemology, it was not something she thought - she knew it. The question of 'unreality' probably never arose in her mind. Should she find out the 'truth' one day, that obviously requires a radical revision of her past beliefs, but it does not retrospectively downgrade what she knew at the time to mere belief.

For biosemiotics, the human objective world (qua systematic belief system) offers possibilities for a sustained critique: ideologies like humanism (comprising anthropocentrism, race and gender discrimination, among other things) can be shown to be mere constructs, unlike the non-human objective world, which cannot be linguistically constructed (and hence cannot be ideological). What humanists say about the non-human objective world, however, is ideological - from the point of view of biosemiotics - and so is idealism (in its denial of hardcore reality). 
Deely chastizes orthodox science for failing to distinguish between objects and things, but his is not a critique of the language of science. The latter is part of the human objective world, while the 'things' themselves are not. In turn, in The Semantics of Science, Harris (2005) criticizes the worldview sustaining the scientific notion of 'objective' reality (in the non-biosemiotic sense), which constitutes at the same time his critique of the 'Language Myth', which he sees as operating in "supercategories" like Science (and equally present in Art, History and Religion). The Harrisian argument is that science owes its existence to the availability of a specific kind of language and a macrosocially institutionalized discourse, upon which membership (and excommunication) ultimately rest. As Harris shows, science tacitly relies on a "surrogationalist semantics", itself divided into two distinct branches: 'reocentrism' and 'psychocentrism'. It is chiefly the reocentric conception of how words get their meaning, namely by 'standing for' the things they are names of, that prevails in orthodox science. It is a languagephilosophy that ties in with the view that the world exists mind-independently and that knowledge of the things that populate the universe (natural units) requires knowledge of the correct linguistic labels, by means of which things can be identified as the same over and over again. Both types of knowledge are assumed to be context-independent. It has been the scientist's job to continuously map the universe, as scientific knowledge progresses, whereby one name gets replaced by a new name (or the name remains but is semantically redefined). Name variation, within a 'reocentric' model of language, must be handled with suspicion and possibly dissolved, i.e. cases in which one and the same thing is known by different names, as well as cases in which the same name refers to different things (Pablé 2009). In either case a disruption of the reocentric ideal (one name-one referent) has occurred. Some names must therefore be rejected (scraped off the linguistic map) on the grounds that they are psychocentrically defined, i.e. they merely "stand for" ideas in the mind. From a Harrisian point of view, either surrogationalist conception of meaning is fallacious for its failure to treat words in relation to the activities they integrate, which is why (for Harris) not even scientific terms are determinate in form or meaning. This critique of the various (segregational) philosophies of language is unique to integrationism and the reasons for it, as we have seen, are semiological. 


\section{Communication as a universal phenomenon?}

The present paper has argued that semiotics and semiology are incompatible, but not primarily for the reasons given by semiotics. The fact that semiotics believes it can include semiology suggests that Peirce and Saussure were like-minded in at least one respect when presenting their programmes for a doctrine of signs and a science of signs, respectively: they both thought that signs exist as abstractions, though neither seems to have realized how strongly this metaphysical assumption was due to literacy, or what Harris (1998: 123) calls the fallacy of "scriptism". On that score, both semiotics and semiology are products of a culture and society imbued with language mythical beliefs. It is interesting to note that in their book on alternative Southern epistemologies, Pennycook and Makoni (2019) extensively discuss 'languages' (count) and 'language' (mass) as ideological products of the Global North, but theirs is not a critique of the metaphysical notion that signs exist as abstractions, which is clearly a product of Western intellectual thought (Harris 2009c). Only Harrisian semiology rejects the reality of abstractions and instead recognizes personal experience as the guide to theorizing communication (in a general sense), and in doing so, I have argued elsewhere, transcends ethnocentrism (Pablé 2019b). While not denying that non-human beings engage in communication, integrationism constitutes a theory of human communication.

Taking a broader theoretical perspective on communication, as semiotics does, necessitates a biological view of ourselves and of our mental activities, which come to be seen as endosemiotic processes. Thus what I call 'my mind' is ultimately caused by the micro-organisms that make it possible for me to live (and to have a mind). However, biosemiotics, like evolutionary biology, requires that we take a detached view of ourselves in order to see ourselves as 'animals' who happened to develop linguistic communication. The integrationist, on the other hand, does not consider 'language' to be what makes us human. One way to define what makes us human, arguably, is to say that we are persons (not in a legal sense), each with his/her unique personal history. It follows that each of us has his/her own communicational biography, which comprises so much more than merely 'linguistic' communication. Deely (2009: 155), in turn, suggests that everything communicates (rocks, stars, plants, etc.). This stance is the very opposite of Harris. Both have their appeals, but require different philosophies of language. Any discipline centred on the sign as its primary theoretical concept operates on certain linguistic beliefs (Pablé 2016). The distinction between 'real definition', i.e. the thing a word stands for, and 'lexical definition', i.e. what a word means (Harris, Hutton 2007), poses a major challenge in this respect which calls for a clear position. Harris (2003: 67) called the conflation of this distinction "deplorable", 
adding that it partly accounts for the "morass in which modern semantics has been floundering for at least hundred years". The distinction is a crucial one - in fact, ontologies and epistemologies will vary depending on the position taken. ${ }^{2}$

\section{References}

Cobley, Paul 2011a. Mythbusting. Language Sciences 33(4): 511-516. https://doi.org/10.1016/j. langsci.2011.04.006

Cobley, Paul 2011b. Sebeok's panopticon. In: Cobley, Paul; Deely, John; Kull, Kalevi; Petrilli, Susan (eds.), Semiotics Continues to Astonish: Thomas A. Sebeok and the Doctrine of Signs. (Semiotics, Communication and Cognition 7.) Berlin: De Gruyter Mouton, 85-114.

Cobley, Paul 2014. Codes and coding: Sebeok's zoosemiotics and the dismantling of the fixedcode fallacy. Semiotica 198: 33-45. https://doi.org/10.1515/sem-2013-0100

Cobley, Paul 2016. Cultural Implications of Biosemiotics. (Biosemiotics 15.) Dordrecht: Springer.

Cobley, Paul 2017. Discussion: integrationism, anti-humanism and the suprasubjective. In: Pablé, Adrian (ed.), Critical Humanist Perspectives. London: Routledge, 267-284. https:// doi.org/10.4324/9781315621760-18

CP $=$ Peirce, Charles Sanders. The Collected Papers of Charles Sanders Peirce. (Hartshorne, Charles; Weiss, Paul, eds. 1931-1935; Burks, Arthur W., ed. 1958.) Cambridge: Harvard University Press. [In-text references are to CP, followed by volume and paragraph numbers.]

Deacon, Terrence 1997. The Symbolic Species: The Co-Evolution of Language and the Human Brain. Harmondsworth: Penguin.

Deely, John 2003. The word semiotics: Formation and origin. Semiotica 146: 1-49. https://doi. org/10.1515/semi.2003.066

Deely, John 2009. Purely Objective Reality. (Semiotics, Communication and Cognition 4.) Berlin: Mouton de Gruyter.

Harris, Roy 1981. The Language Myth. London: Duckworth.

Harris, Roy 1996. Signs, Language and Communication. London: Routledge.

Harris, Roy 1998. Introduction to Integrational Linguistics. Oxford: Pergamon.

Harris, Roy 2003. History, Science and the Limits of Language. Shimla: Indian Institute for Advanced Study.

Harris, Roy 2005. The Semantics of Science. London: Continuum.

Harris, Roy 2006. Integrational linguistics and semiology. In: Keith, Brown (ed.). Encyclopedia of Language and Linguistics. Oxford: Elsevier, 714-718. https://doi.org/10.1016/B0-08044854-2/04482-5

Harris, Roy 2009a. The integrational conception of the sign. In: Harris, Roy, Integrationist Notes and Papers 2006-2008. Gamlingay: Bright Pen, 61-82.

Harris, Roy 2009b. After Epistemology. Gamlingay: Authors Online.

Harris, Roy 2009c. Rationality and the Literate Mind. London: Routledge.

Harris, Roy 2010. Linguistic Inquiry. Unpublished manuscript.

Harris, Roy; Hutton, Christopher 2007. Definition in Theory and Practice. London: Continuum.

2 Acknowledgements. The author would like to thank Charlotte Conrad, Paul Cobley and Johan Siebers for comments on an earlier draft. 
Hoffmeyer, Jesper 1996. Signs of Meaning in the Universe. Bloomington: Indiana University Press.

Kull, Kalevi 2010. Umwelt and modelling. In: Cobley, Paul (ed.), The Routledge Companion to Semiotics. London: Routledge, 43-56.

Kull, Kalevi 2011. The architect of biosemiotics: Thomas A. Sebeok and biology. In: Cobley, Paul; Deely, John; Kull, Kalevi; Petrilli, Susan (eds.), Semiotics Continues to Astonish: Thomas A. Sebeok and the Doctrine of Signs. (Semiotics, Communication and Cognition 7.) Berlin: De Gruyter Mouton, 223-250.

Pablé, Adrian 2009. The 'dialect myth' and socio-onomastics: The names of the castles of Bellinzona in an integrational perspective. Language and Communication 29(2): 152-165. https://doi.org/10.1016/j.langcom.2008.12.004

Pablé, Adrian 2016. Global semiotics vs. human semiology. Chinese Semiotic Studies 12(1): 25-43. https://doi.org/10.1515/css-2016-0004

Pablé, Adrian 2019a. In what sense is integrational theory lay-oriented? Notes on Harrisian core concepts and explanatory terminology. Language Sciences 72(1): 150-159. https://doi. org/10.1016/j.langsci.2018.10.001

Pablé, Adrian 2019b. Is a general non-ethnocentric theory of human communication possible? An integrationist approach. Lingua. Article 102735. https://doi.org/10.1016/j. lingua.2019.102735

Pablé, Adrian; Hutton, Christopher 2015. Signs, Meaning and Experience: Integrational Approaches to Linguistics and Semiotics. (Semiotics, Communication and Cognition 15.) Berlin: Mouton de Gruyter.

Pennycook, Alastair; Sinfree Makoni 2019. Innovations and Challenges in Applied Linguistics from the Global South. London: Routledge.

Petrilli, Susan 2011. About a master of signs starting from The Sign \& Its Masters. In: Cobley, Paul; Deely, John; Kull, Kalevi; Petrilli, Susan (eds.), Semiotics Continues to Astonish: Thomas A. Sebeok and the Doctrine of Signs. (Semiotics, Communication and Cognition 7.) Berlin: De Gruyter Mouton, 293-306.

Petrilli, Susan 2015. Language, communication, and speech: Human signs in global semiosis. Semiotica 204: 173-237. https://doi.org/10.1515/sem-2014-0092

Petrilli, Susan; Ponzio, Augusto 2011. A tribute to Thomas A. Sebeok. In: Cobley, Paul; Deely, John; Kull, Kalevi; Petrilli, Susan (eds.), Semiotics Continues to Astonish: Thomas A. Sebeok and the Doctrine of Signs. (Semiotics, Communication and Cognition 7.) Berlin: De Gruyter Mouton, 307-330.

Saussure, Ferdinand de 1983. Course in General Linguistics. (Harris, Roy, trans.) London: Duckworth.

Sebeok, Thomas 1979. The Sign \& Its Masters. Texas: The University of Texas Press.

Sebeok, Thomas 1986. I Think I Am a Verb. New York: Plenum Press.

Uexküll, Jakob von 1982. The theory of meaning. Semiotica 42(1): 25-82. https://doi. org/10.1515/semi.1982.42.1.25 


\section{Интегрирующие биосемиотики. С семиологической точки зрения}

Данная работа представляет собой исследование в области «философии семиотики». Она сосредоточена на критическом подходе к концепции знаков Пирса, которая лежит в основе биосемиотики и глобального взгляда на знаки. В настоящей работе рассматриваются вопросы, представляющие онтологический и эпистемологический интерес, с семиологической отправной точкой. Вдохновителем настоящей статьи служит интеграционизм Роя Харриса, подход к человеческому общению, отвергающий соссюрианскую семиологию - общую цель семиотики Пирса. Интеграционизм объясняет знаки, связанные с человеческой деятельностью. Он разделяет с биосемиотикой представление о реальности как о видовой специфике, но занимает скептическую позицию в отношении исследования нечеловеческих знаков на том основании, что он подразумевает метаязык, невосприимчивый к радикальной неорределенности знака. Интеграционисты воспринимают эту неопределенность как отправную точку для своих размышлений о человеческом общении.

\section{Biosemiootika lõimimine: Semioloogilisest vaatevinklist}

Käesolev artikkel on uurimus „semiootika filosoofiast“. Selles keskendutakse ühele kriitilisele viisile läheneda Peirce’i märgikontseptsioonile, mis on aluseks biosemiootika ning märkide globaalsest perspektiivist nägemisele. Selles käsitluses puudutatakse ontoloogilist ja epistemoloogilist huvi pakkuvaid küsimusi, võttes kasutusele selgelt semioloogilise mõõdupuu. Semioloogia, millest käesolev kriitika tõukub, on Roy Harrise integratsionism, lähenemine inimkommunikatsioonile, milles hüljatakse Saussure’i semioloogia kui Peirce’i semiootika tavaline märklaud. Integratsionism seletab märke seoses inimtegevustega. Biosemiootikaga jagab see seisukohta, et reaalsus on liigispetsiifiline, ent jääb skeptiliseks mitteinimmärkide uurimise suhtes põhjendusega, et sellega kaasneks metakeel, mis ei ole vastuvõtlik märgi radikaalse määramatuse suhtes. Integratsionistide jaoks on see määramatus lähtekoht, millelt reflekteerida inimkommunikatsiooni üle. 